\title{
Class 1/4 Histone Deacetylase Inhibitor OKI-179
}

National Cancer Institute

\section{Source}

National Cancer Institute. Class 1/4 Histone Deacetylase Inhibitor OKI-179. NCI

Thesaurus. Code C160606.

An orally bioavailable inhibitor of the histone deacetylase (HDAC) subtypes 1 and 4 , with potential antineoplastic activity. Upon administration, class 1/4 HDAC inhibitor OKI-179 targets, binds to and inhibits the activity of HDAC1/4. This results in an accumulation of highly acetylated chromatin histones, the induction of chromatin remodeling and an altered pattern of gene expression. This consequently results in a selective transcription of tumor suppressor genes, tumor suppressor protein-mediated inhibition of tumor cell division and an induction of apoptosis in tumor cells that overexpress HDAC1/4. HDAC, which is upregulated in many tumor cell types, deacetylates chromatin histone proteins and plays a key role in transcriptional regulation and cell cycle progression. 